\title{
車載カメラによる実時間画像処理とその AR 技術に基づく 表示方式によるカーナビへの応用 Real-time Video Processing by a Car-mounted Camera and Its Application to Car Navigation Systems by an Augmented Reality-based Display Method
}

\author{
澤野弘明 ${ }^{\dagger}$, 岡田 稔 ${ }^{\dagger}$ \\ Hiroaki SAWANO ${ }^{\dagger}$ and Minoru OKADA ${ }^{\dagger \dagger}$ \\ $\dagger$, †早稲田大学大学院情報生産システム研究科
}

$\dagger$, †† Graduate School of Information, Production and Systems, Waseda University

† burai@okada-lab.org, †† mokada@waseda.jp

\begin{abstract}
アブストラクト：本論文では，拡張現実感 $(A R)$ 技術を用いた表示方式 (以下，本表示方式) のカーナビゲーションシステム (以下，本システム)を提案する . 本システムでは , (I) 走行中 の車載カメラから実写動画像の取得，(II) コンピュータビジョン技術による道路幾何情報の抽 出, (III) $C G$ 技術による $3 D-C G$ シーンのリアルタイム生成, ( IV) 元の動画像とオーバレイ 表示, という戦略をとる.本システムの利点は, 道路幾何情報のリアルタイム収集·解析によ る詳細な $3 D-C G$ モデリングデータ作成コストの削減， $A R$ 技術によるカーナビゲーション表 示における瞬時の視認性の向上，である . 本表示方式の有効性についてシミュレーションを用 いて被験者 100 人に対してアンケートした結果，85\%以上の被験者から従来の $3 D-C G$ によ 表示方式に比べ, 本表示方式の方か瞬時の視認性が高いという回答が得られた . また, 実写動 画像を入力情報として，簡易な $A R$ 表示のみを行う試作システムによる実験を行った。さら に，本表示方式を実装するためにシステム実装時に考慮すべき点とアルゴリズム上の問題点 をまとめ, 今後の課題を示す .
\end{abstract}

Abstract: We propose a car navigation system using an Augmented Reality (AR) technique that consists in (I) taking a real-time video using an equipped camera on front of the vehicle, (II) extracting road geometry information from the video by a Computer Vision technique, (III) modeling three-dimensional Computer Graphics (3D-CG) by a CG technique, and (IV) overlaying the 3D-CG into the real-time video. There are two advantages in our system. One is the reduction in cost to model detailed 3D-CG data by collecting and analyzing road geometry information in real-time. The other is to improve high instantaneous visibility in car navigation display by an AR technique. The result of the investigation of comparing an ordinary display method with our display method for availability for car navigation is that 85\% of 100 examinees have preferred our display method instead of the ordinary 3D-CG display method. The challenges and future works of the proposed method simple AR system are described by the experimental result of an implementation in prototype phase and a simulation of our method.

キーワード : カーナビゲーションシステム , 拡張現実感技術 , 表示方式 , コンピュータビジョ ン技術，コンピュータグラフィクス技術

Keywords: Car Navigation System, Augmented Reality Technique, Display Method, Computer Vision Technique, Computer Graphics Technique 


\section{1 はじめに}

カーナビゲーションシステム (以下 , カーナ ビ) は 1981 年に本田技研がジャイロ式カーナ ビを発売 [1] して以来, 自車位置推定精度の向 上による正確な案内表示や樣々な表示方式の 開発など，急激な成長を遂げており，この分 野では日本は世界をリードしている．一方で， カーナビの機能・操作の複杂倠化に伴い，1999 年 11 月に道路交通法の改訂により運転時の カーナビ画面の注視が禁止になった .もとも と運転者 (ユーザ) がカーナビ画面を見続け ることは難しく，ユーザにとって瞬時の視認 性 ${ }^{1}$ が高いカーナビ表示が必要である $[2,3]$. 運転中に連続してカーナビ操作をする場合， 視線が前方からカーナビ画面に移動し始めて から再び前方へ戻るまでの時間は 1 秒程度と いう結果 [3] が麻生らによって報告されてい る.また , こ二数年, 高度交通システム (ITS: Intelligent Transportation Systems) の開発 分野の “ナビゲーションの高度化” に関する研 究も盛んに行われている $[4,5]$. 瞬時の視認性 の向上のために, 日本では, 上面図の二次元表 示,鳥瞰図やドライバーズビューなどの三次元 CG (3D-CG: Three-dimensional Computer Graphics) 表示が一般化している . 本研究で は, ユーザが見る視界風景に最も近いドライ バーズビュー表示方式に着目する .

都心部の表示では, 利用者が多いため, 詳 細な 3D-CG モデリングデータを利用して周 辺の案内情報を提示している .一方で, 郊外 においては二次記憶媒体に含まれるモデリン グ情報が少ないため，特徵のある建物のみを $3 \mathrm{D}$ ランドマーク等を利用して提示している。 兴のため, 実際の風景 (図 1(b)) とカーナビ表 示 (図1(a)) を対応付ける，すなわち，同一の シーンであると認識することが困難な場合が 少なからずあり，瞬時の視認性が極めて低い と考えられる. 詳細なモデリングデータの情 報収集・作成のために，ヘリコプタを用いて

\footnotetext{
${ }^{1}$ 本研究ではユーザの瞬時の目視による案内情報の 認識・理解のしやすさを瞬時の視認性と呼び，重要視 している。
}

建物を複数方向から撮影し，乥の実写画像に 基づいて $3 \mathrm{D}-\mathrm{CG}$ モデリングデータを作成す る手法 [6] が Zhang らによって提案されてい る.このように詳細なデータを作成するため には，膨大なデータ量の記憶媒体と光のため の情報収集コストが必要であり，日本中のあ らゆる風景に対応することは現実的ではない．

本論文では, 以下の特徵を持つカーナビ(以 下，本システム) $[7,8,9,10,11,12]$ の表示方 式と光のための構成方式を提案する .すなわ ち，(I) 車載カメラを利用した走行中での実 写動画像の取得, (II) コンピュータビジョン (CV: Computer Vision) 技術による道路幾何 情報の抽出，(III) リアルタイムの 3D-CG 生 成, (IV) 実写動画像とオーバレイ表示, と いう戦略による拡張現実感 (AR: Augmented Reality) 技術を利用した表示方式 (以下，本 表示方式) (図 1(c)) である. 本システムによ り，道路幾何情報のリアルタイム収集·解析 による詳細な $3 \mathrm{D}-\mathrm{CG}$ モデリングデータコス 卜の削減， AR 技術による瞬時の視認性の向 上, が期待される．本論文では, アンケート を用いて本表示方式の有効性を検証し，試作 システムによる実験結果を示す .ここで試作 システムは道路端抽出結果に基づいた簡易な $\mathrm{AR}$ 表示を行うものであり，案内機能は実装 されていない.さらに本システムにおけるシ ステム実装時に考慮すべき点とアルゴリズム 上の問題点を考察し，本システムを実装する ための指針を示す .

\section{2 関連技術}

\section{1 現在のカーナビ表示}

現在のカーナビ表示では, 二次記憶媒体か らの地図情報, GPS (Grobal Positioning System) からの自車位置情報 (緯度, 経度), ジャ イロからの姿勢情報, 自車速度情報などの入 力情報に基づいて $2 \mathrm{D}-\mathrm{CG}$ ，もしくは $3 \mathrm{D}-\mathrm{CG}$ による案内表示を提示している . 高速道路の インターチェンジなどの 3D-CG による案内 


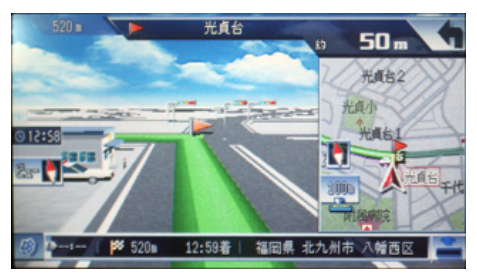

(a) Ordinary display

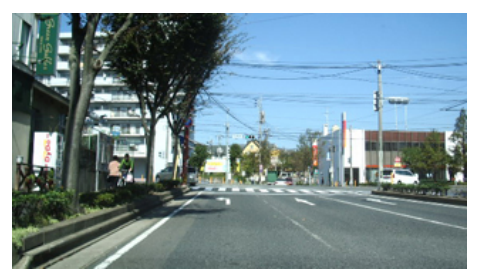

(b) Actual scenery

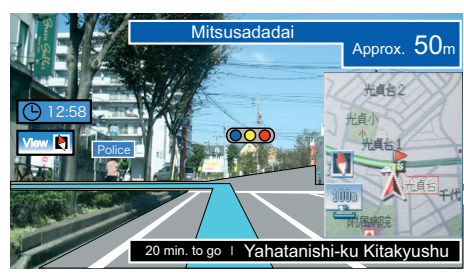

(c) Proposed method

図 1: 実際の風景と対応したカーナビ表示

Fig. 1: An actual window scenery in a suburb and car navigation display images

表現が難しい場所における表示では, デザイ ナによるイラストを利用して誘導している．

しかし, 郊外においては, 利用頻度が低い ため,詳細な道路幾何情報を収集・解析してい ない. 弚のため, 単純な案内表示を提示する 場合が多い. 郊外のカーナビ表示と光れに対 応する実際の風景の例を図 $1(\mathrm{a})$, (b) に示す。 図1(b)の実際の風景では, 左前方にマンショ ンが存在するにも関わらず, 図 1 (a) のカーナ ビ表示では, 交番を示すランドマークしか表 示されていない.この場合，実際の風景から 交番の建物の存在を知ることは難しく，同一 の場所として知覚するための瞬時の視認性が 極めて低くなる典型例と考えられる．この問 題は，現在の日本のカーナビメーカ約 20 社の 製品においてもほぼ同樣の状況である．

\section{$2.2 \mathrm{AR}$ 技術を利用した案内表示}

$\mathrm{AR}$ とは，実写画像の対応位置に仮想物体を 配置し，ユーザに周辺環境を知覚させるため の情報を提供する技術である $[13]$. AR 技術を 利用した誘導·案内として, カメラを付属した 携帯情報端末 (PDA: Personal Digital Assistant)やヘッドマウントディスプレイ (HMD: Head Mounted Display) を利用したシステム か提案されている $[14,15]$. 設備の設計図面や 点検履歴などの樣々な情報を扱うプラント管 理では， IC タグやマーカを使用し， AR 技術 により実写画像の対応した位置に, 設備の詳 細な情報を付加して現場の保全員に提供して いる [13] . これにより使用設備のマニュアル
の管理コストの削減が期待される . また, 天 目らや寺田らは屋外の案内として, 地図情報 と位置情報を用いてカメラからの実写動画像 の対応位置に建物の情報を付加して案内する 手法 $[14,15]$ を提案している. AR 技術を利用 した案内表示は, フル CG を利用した案内表 示よりも実際の風景との対応付けがしやすい ため, 瞬時の視認性が向上すると考えられる .

\section{3 死角領域を考慮した表示法}

カーナビ表示では，建物等の遮蔽物による 死角領域の案内情報の提示も重要課題のひと つである.従来のカーナビでは , 3D-CGによ る建物を半透明表示することにより，死角領 域の案内情報を提示する方式も採用されてい る.津田らは複合現実感 (MR: Mixed Reality) 技術における死角領域の案内表示では, 遮蔽 物をワイヤーフレームで提示することが有用 であることを報告している $[16]$. 津田らの手 法では, あらかじめ撮影された死角領域の映 像のテクスチャを用いており, 膨大な量の映 像データが必要となるため, 本システムに適 用することは難しい，乥こで本システムでは， 死角領域の案内情報を提示するために実写動 画像上で遮蔽物に対して CG 道路画像を被せ て案内表示する方法 [11] を検討している．

\section{$2.4 \mathrm{AR}$ 技術を利用したカーナビ}

$\mathrm{AR}$ 技術を利用したカーナビの関連研究と して, 実写動画像に対応する位置に案内情報 


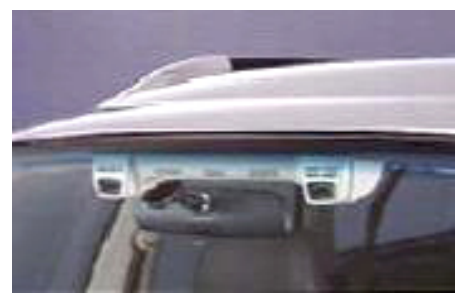

(a) On the reserve sides of the room mirror

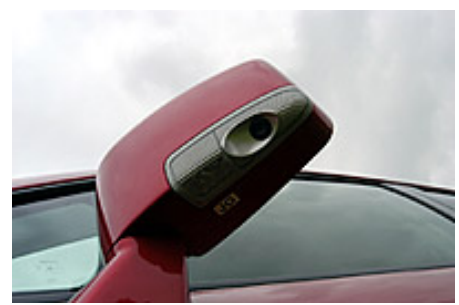

(b) On a door mirror

図 2: カメラ位置の例

Fig. 2: Examples of position of the camera

を提示するシステム $[17]$ が提案されている また，Hu らは実写動画像から道路幾何情報 を抽出し, 抽出結果と地図情報からの道路形 状モデルのマッチングによりカメラの姿勢情 報を求め, 対応する位置に案内情報を提示す るというカーナビ方式 [5] を提案している.こ れは案内システムという点で本研究とゴール は同じである．しかし，実写動画像には案内 として必要ではない情報が多いため，実写動 画像に対して進行方向を示す矢印のみを表示 した場合においても，曲がるべき交差点など が確認しがたいという問題が生じることが考 えられる.光れに対して筆者らが提案するシ ステムでは，CG 画像を用いることにより不 必要な情報を隱蔽し，案内に寄与する情報の みを提示することが特徽である．ここで 4.2 節で後述するように，CG 画像はユーザが選 択的に表示.非表示を決定できることを想定 している．さらにこれらの関連システムの方 式では地図情報が最新でない場合に不整合が 生じると考えられる，一方，筆者らが提案す るシステムでは, 地図や光の他の情報を参照 入力として CV 技術により道路幾何情報を抽 出することを前提としており，地図情報が末

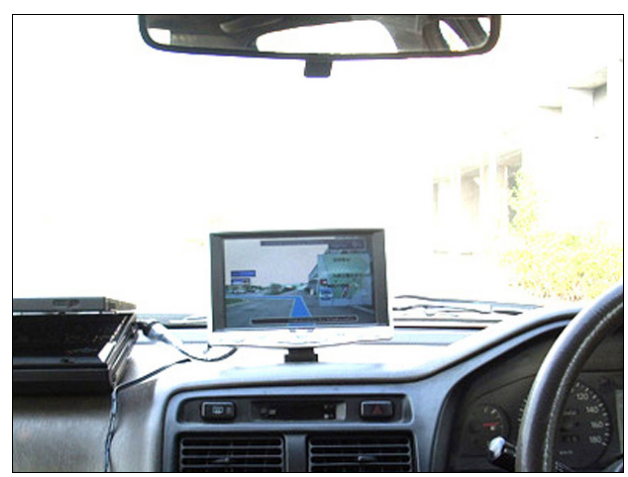

図 3: 車蟿に設置した試作システム

Fig. 3: Prototype system installed in a vehicle

更新の場合においても，弚の時点での尤もら しい表示を提示できる．本表示方式は，従来 方式のフル CG 表示とともにカーナビの複数 の表示方式のひとつとして位置付けし，ユー ザが任意に選択できることを前提とする．

\section{3 本カーナビ表示方式}

\section{1 概要}

本研究では, $\mathrm{AR}$ 技術をカーナビ表示に応 用する (図 1(c)). 現在のいくつかの車種では， 見通しの悪い交差点の左右確認, 車輌横の溝 の確認，後進時の後方視界確保を目的とした カメラが搭載されている(図 2) .このように 車輌にカメラを搭載することは，技術的，コ スト的に問題がないため，本システムでは車 䤴前部に設置したカメラからの実写動画像の 利用を前提とする . 本システムは, AR 技術 を利用してカーナビ表示と実際の風景の対応 付けを容易にし，瞬時の視認性を向上させる． また，本システムは，従来のカーナビに使用 される多種の入力情報と CV 技術を併用する ことで, 自車位置精度の向上や効率的な道路 幾何情報の収集などといった交通環境認識と 兴の応用の分野での大きな貢献か期待される. 図 3 に車輌ダッシュボードに設置した試作シ ステムを示す． 


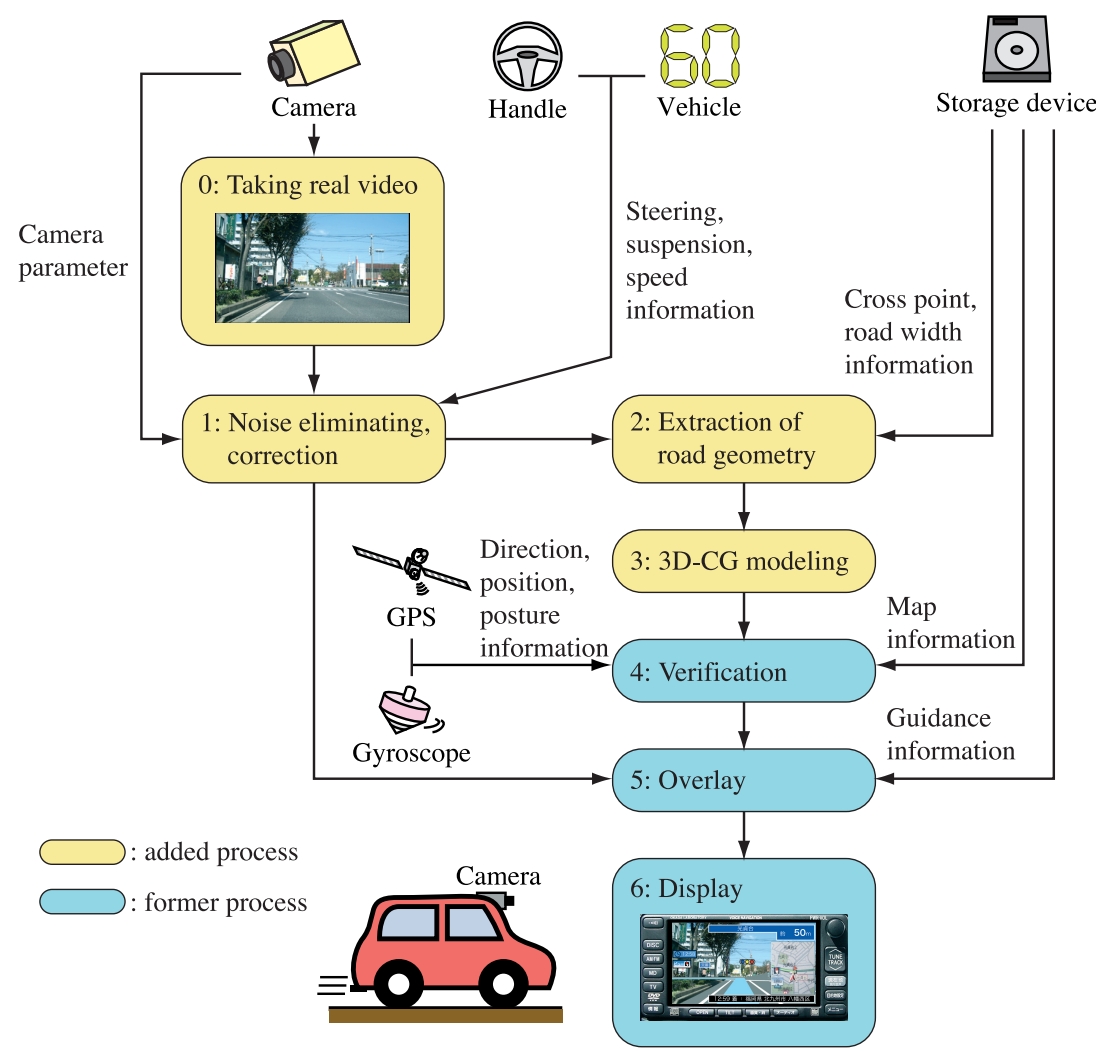

図 4: 本システムの概要

Fig. 4: The outline of the AR-based car navigation system

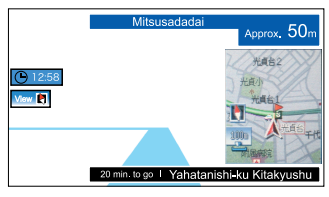

(a) Optional information

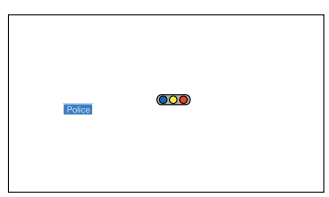

(b) Symbol

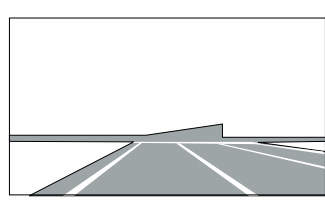

(c) CG road

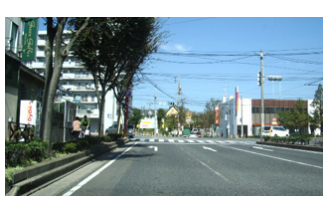

(d) Real-time video

図 5: 4 層のレイヤー

Fig. 5: Four layers

\section{2 処理手順}

本システムの構成及び処理の概要を以下に 示す (図 4).

0. 車轚前部のカメラから実写動画像の取得

1.ノイズ除去, 幾何補正

2. CV 技術による道路幾何情報の抽出

3. CG 技術による道路幾何情報抽出結果に 基いた 3D-CG のレンダリング

4. 従来のカーナビに使用されている案内情 報と道路幾何情報を照合

5. 3D-CG 画像を実写動画像にオーバレイ

6. 表示

ここで, 処理手順の番号と図 4 中の番号は対 応している。

\section{3 レイヤー構造}

本表示方式におけるフレームバッファでは， 従来のカーナビ表示と同樣に図 5,6 に示す ような 4 層からなるレイヤー構造を用いる． 使用するレイヤーは, 上層から , (a) ユーザ の好みによって変更される選択可能な付加情 報，(b) 信号機や建物の名前を示すシンボル， (c) 道路幾何情報抽出結果に基づいた CG 道 路，(d) 車載カメラからの実写動画像，であ る. 本システムのような $\mathrm{AR}$ 表示において， レイヤー構造を用いることで, 各レイヤー毎 の表示. 非表示の切り替えなどの操作 . 管理 が容易になる。 


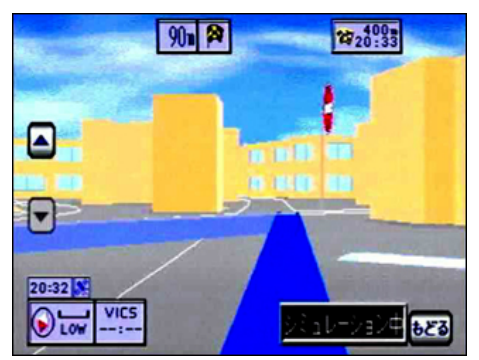

(a) Ordinary display

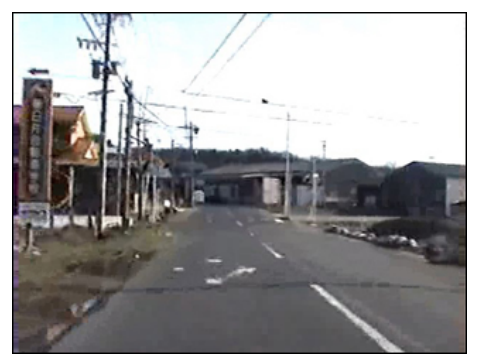

(b) Actual scenery

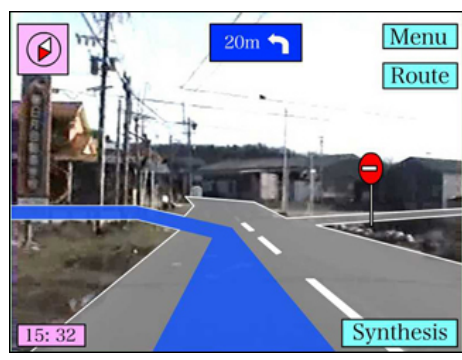

(c) Simulation

図 7: アンケートに使用した実際の風景と対応したカーナビ表示 (郊外)

Fig. 7: An actual window scenery and car navigation display images for questionnaire (suburbs)

(a) Optional information

(b) Symbol . . . . . . . . .

(c) CG road . . . . . . . .
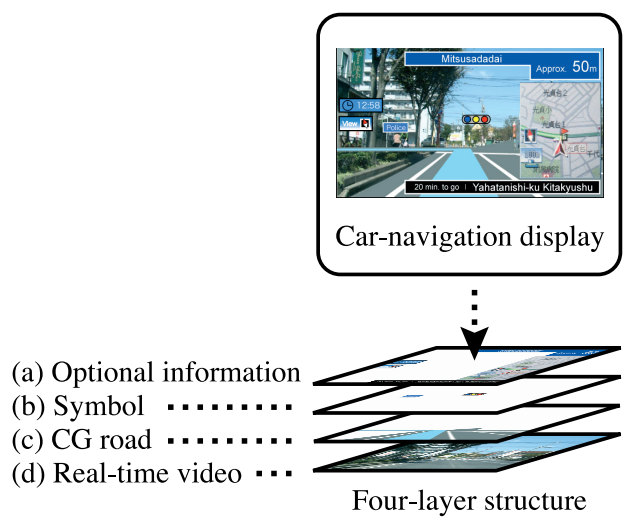

図 6:レイヤー構造

Fig. 6: Layer structure

\section{4 実験と考察}

\section{1 視認性の評価実験}

本表示方式の瞬時の視認性についての有効 性を検証するため, 2 種類の対照システムを用 いた主観評価実験 [20]による街頭アンケート を実施した [12].被験者はカーナビを知ってい

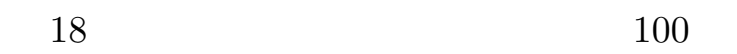
ある.対照カーナビは(株)ケンウッド製 DVZ2081M (2000 年モデル), 本システムはアン ケート当時では未実装のため, Macromedia Flash MX でシミュレーションした. 実風景 の場所は都心部と郊外 (図 7) の 2 種類を使用 した.車載していないノートPCで表示して アンケートを行った . 事前に見やすさとわか りやすさを次のように定義し, 被験者に意識
させた上で実験を行った .

見やすさ カーナビ表示として見るのに具合 が良いこと.

わかりやすさ ナビゲーションとして理解する ことが容易であること．

アンケート方法は以下の通りである .

1. 実風景と乥れに対応した従来の $3 \mathrm{D}-\mathrm{CG}$ カーナビ表示を並べて提示 .

2. 実風景と光れに対応した本カーナビ表示 におけるシミュレーションを並べて提示．

3. 2 つのカーナビ表示を並べ, 両者の見や すさ，わかりやすさを聞き取り調査 .

なお，本表示方式におけるシミュレーション の実験条件として，3D-CG 道路は背景に対し て $20 \%$ 透過表示(透過率 $\alpha=0.2,4.2$ 参照)し， 音声による案内指示は行わない. 対照カーナ ビの表示に近付けるためメニューボタン, 方 位情報, 標識, 時計, 走行ルート案内, 国道 標識のウインドウ・アイコンを付加した . ま た，画面更新を約 $2[\mathrm{fps}]$ としている .

カーナビ表示の比較のアンケート結果を表 1 に示す. カーナビ表示の比較の結果, 見やす さについては $85 \%$, わかりやすさについては $90 \%$ の被験者が従来の 3D-CG のカーナビ表 示に比へてて本表示方式の方が良いと回答した。 また，性別に関わらず，本表示方式の有効性 が示唆された . 従来の 3D-CG のカーナビ表 示を支持した被験者から，見やすさについて 
表 1: カーナビ比較アンケート結果 Tab. 1: Enquete results of car navigation comparison

(a) Acceptability (head-count)

\begin{tabular}{l|c|c|c}
\hline Option & Male & Female & Total \\
\hline 3D-CG & 4 & 4 & 8 \\
Even & 4 & 3 & 7 \\
Our method & 39 & 46 & 85 \\
\hline \multicolumn{1}{c}{ Total } & 47 & 53 & 100 \\
\hline
\end{tabular}

(b) Understandability (head-count)

\begin{tabular}{l|r|c|c}
\hline Option & Male & Female & Total \\
\hline 3D-CG & 4 & 1 & 5 \\
Even & 1 & 4 & 5 \\
Our method & 42 & 48 & 90 \\
\hline \multicolumn{1}{c}{ Total } & 47 & 53 & 100 \\
\hline
\end{tabular}

は建物が単純化された表示の方が良いという 回答が得られ，わかりやすさについては都心 部では駐車車輌などの必要でない情報が増加 するためである，という回答が得られた．

また , アンケートの自由回答において，

- CG 道路によって走行車や路上駐車車輌， 歩行者などが表示されない方が良い

- CG 道路を合成せず案内情報や建物の情 報のみの合成の方が良い

という相反する意見が得られた .この結果は CG 道路の透過率 $\alpha$ を可変とすること (4.2) の有効性を示している .

今回のアンケートでは, ノイズ等が少ない 良好な道路シーンのシミュレーションにおけ る本表示方式の有効性を示した . しかし実際 の道路シーンでは複杂隹な道路形状, 天候や夜 間などといった照明の変化, 周辺車輌などの 有無が考えられる．樣々なシーンにおける本 表示方式の有効性を検証するために，これら を考慮したアンケート調査とともに，提案シ ステムを実装し，実体験に基づく調査が必要 である .
表 2: 道路の透過率の変化によるユーザの支持 Tab. 2: Enquete result of user acceptances with changing road permeability $\alpha$

\begin{tabular}{c||c|c|c||c}
\hline Permeability $\alpha$ & 0.0 & 0.5 & 1.0 & Total \\
\hline Supported persons & 2 & 4 & 4 & 10 \\
\hline
\end{tabular}

\section{2 道路表示における 透過率}

$\mathrm{CG}$ 道路を透過表示するために， $\alpha$ ブレン ドすることを検討する.背景画像を $B, C G$ 道

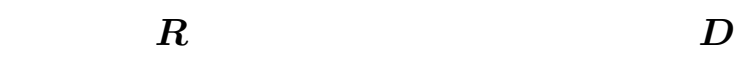
は次式のように $\boldsymbol{R}$ と $\boldsymbol{B}$ 透過率 $0 \leq \alpha \leq 1$ に よる凸結合として決定される．

$$
\boldsymbol{D}=(1-\alpha) \boldsymbol{R}+\alpha \boldsymbol{B}
$$

$\mathrm{CG}$ 道路の透過率に対する個人差を調査す るために，CG 道路の透過率が異なる画像を被 験者 10 名 (男性 9 名, 女性 1 名, 平均 24.4 歳) に対してアンケートを行った.本実験て使用し た画像は図 8 に示すように $\alpha \in\{0.0,0.5,1.0\}$ に対応する 3 種類である . アンケート結果を 表 2 に示す .アンケート結果により，カーナビ 表示に対する瞬時の視認性において, 少数サ ンプルではあるが個人差が生じることが確認 された . すなわち CG 道路の透過率を固定值 にするのではなく，つまみなどにより，ユー ザが自在に変更できるようにして対応するこ とが望ましい。

本表示方式には本節のような直接目視可能 な物体の隠蔽表示と 2.3 で述べたような死角 領域に対する案内表示の相反する問題が存在 する．ユーザによってカーナビ表示に対する 感覚的な受容性が異なるため, 選択的に表示 ·非表示を決定できることか望ましい.

\section{3 試作システムによる本カーナビ表示}

車輌の助手席に設置したカメラ (図 9) から あらかじめ撮影した実写動画像を用いて, 試 作システムによる実験を行う .ここで図 3 の 試作システムとは異なり，車載していない計 


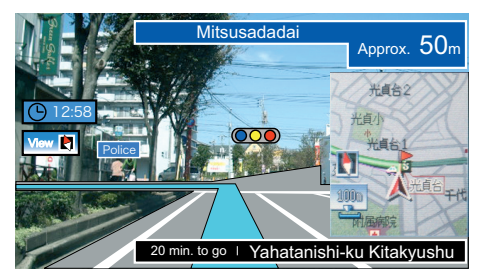

(a) $\alpha=0.0$

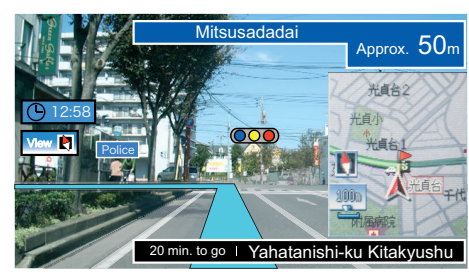

(b) $\alpha=0.5$

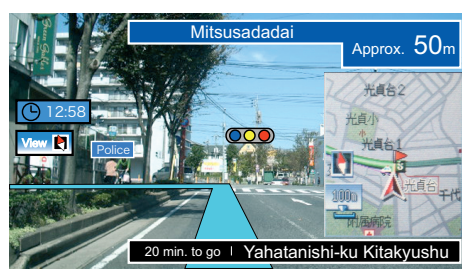

(c) $\alpha=1.0$

図 8: CG 道路の透過率の変化の例

Fig. 8: Examples of change of CG road permeability $\alpha$
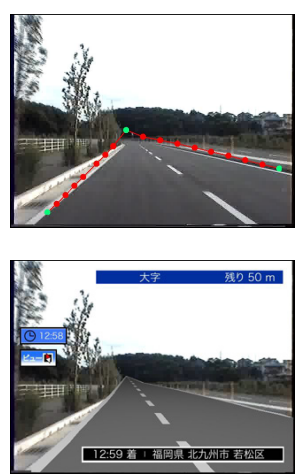

(a) frame 1
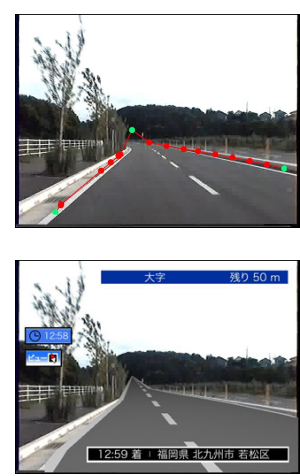

(b) frame 2
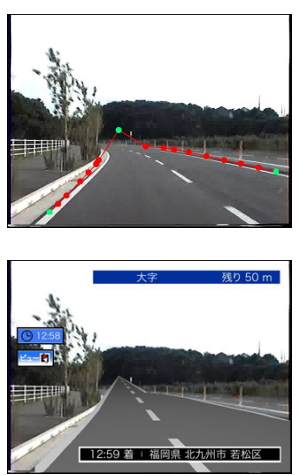

(c) frame 3
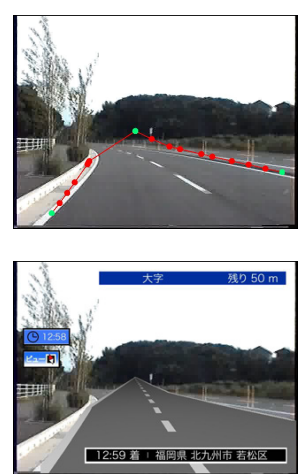

(d) frame 4
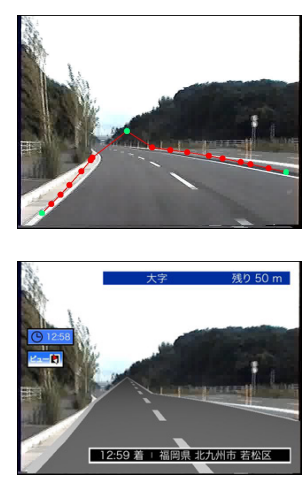

(e) frame 5

図 10: CV 技術による道路端抽出結果 (上段) を利用した本カーナビ表示 (下段)

Fig. 10: Car navigation display (lower row) with road extraction results (upper row) by a CV technique

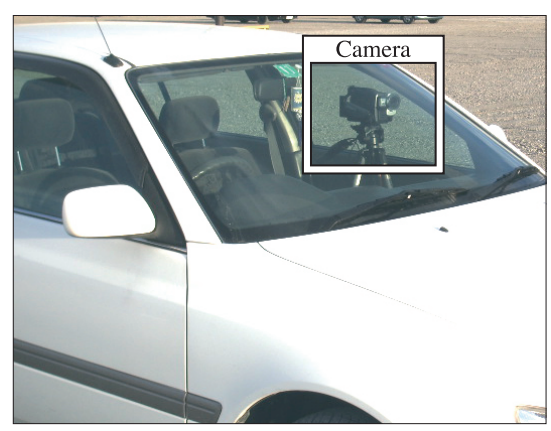

図 9: 車内に設置されたカメラ

Fig. 9: Camera mounted on a vehicle

算機を使用する．CVによる道路幾何情報抽出 には，Sawano らによる道路端抽出法 $[18,19]$ を使用し，入力情報は実写動画像のみとする . 画像サイズは $640 \times 480[$ pixel] とし，実験は RedHat Linux $9+$ gcc, Athlon MP 2200+ dual 環境で行う. 図 10 に道路端抽出結果 (上 段) と道路などの CG 画像をオーバーレイ表 示した動画像の一部 (下段) を示す．ここで道 路端が明瞭で他の車輌が走行していない直線 道路の実写動画像を使用した . また，CG 道路 にはPhong の拡散面モデルによるシェーディ ングを用い，都市名や時刻などを示すウィン ドウにはあらかじめ用意した画像を使用した . 図 10 の実験結果より,遠方のカーブの形状 及び消失点が正確に抽出できておらず, 道路 端抽出の精度として充分ではない . また今回 の実験では周辺車輌や木の影等のノイズを含 んでいないという良好な条件である.実際に 提案システムを利用するために，これらのノ イズ等を考慮したロバストな道路幾何情報の 抽出が望まれる。

さて ,現在のカーナビ表示の描画速度として 
$2 \sim 5[\mathrm{fps}]$ が要求されているが, 試作システム による処理時間は 1 フレーム当たり $2,380[\mathrm{~ms}]$ (0.42[fps]) 費やし，処理速度は充分ではない． 兴の内訳は道路幾何情報抽出 $2,196[\mathrm{~ms}]$,レン ダリング $156[\mathrm{~ms}]$ ，オーバレイ処理 $28[\mathrm{~ms}]$ で ある . 処理時間によっては, カーナビ表示に 使用する風景と実際の風景にタイムラグが生 じることが考えられる .これは目的の交差点 の数 $\mathrm{m}$ 前から実写動画像における対応する位 置に, 矢印等の案内指示を提示することで対 応できると考えられる . さらに上面図や従来 のカーナビに使用される音声による案内を併 用して対応する予定である . また, 最近では カーナビに衛星写真を用いるシステムも存在 するため，乥れらの利用も検討する．

アルゴリズムの効率化により処理速度を向 上する予定であるが, 本研究では八ードウェ アで実装することにより $30[\mathrm{fps}]$ 以上の処理を 目指している . 高速な描画の更新 (画面のリ フレッシュ) が瞬時の視認性が高い表示とは 限らないため, 提案システムでは, 画面更新 と内部での動画像処理のフレームレートは別 管理として同期させない方が良いと考えられ る .ここでハードウェアで実装するとは道路 幾何情報抽出専用に LSI 化することを想定し ており，LSI 化することにより数十から 100 倍以上の処理速度向上が期待される . さらに 現在では FPGA (Field Programmable Gate Array) といったプログラミング可能な LSIが 提供されているため，プログラムをLSI 化す ることは容易である．

試作システムでは, 実写動画像からの道路 端抽出及び抽出結果に基づいた簡易な $\mathrm{AR}$ 表 示しかしておらず, 現在案内システムとして は実装されていない，地図情報を利用した案 内機能の実装が今後の課題である .

\section{4 問題点とその対策}

本表示方式を現実の車載システムとして実 装するためには, 樣々な問題点が予想される . 予想される問題点を以下の 2 つ分類, 整理
し，今後の指針とする．

・ システム実装時に考慮すべき点

・アルゴリズム上の問題点

問題点と炎の対策を以下に示す.

\subsection{1 システム実装時に考慮すべき点}

a) 低解像度のカメラの使用

車載システムではコストの制約を考慮し なければならないため，携帯電話等に使用 されるような安価な CCD カメラユニット の使用を前提とする必要がある.最近の携 帯電話に使用されるカメラの有効画素数は 320 万程度である.ここで携帯電話に使用 されている有効画素数は物理的な総画素 数であり, 論理的な画素数は通常, RGB の各画素を 1 組とし，有効総画素数の $1 / 3$ である．また同携帯カメラによる動画像 の場合，QVGA サイズ $(240 \times 320[$ pixel] $)$ ， $15[\mathrm{fps}]$ て撮影される.このことから低解像 度のカメラで道路幾何情報を抽出するとと もに，瞬時の視認性の高い表示をしなけれ ばならない .

b)レンズによって生じる影響

レンズに傷が生じた場合, 動画像の特性を 利用して対応する . また, カメラの設置状 況によってレンズが污れる場合は, 専用ワ イパーの使用も検討する . 事故などでカメ ラの視線方向がずれた場合は, 幾何補正に よる対応やカメラに異常が生じているとい う情報を提示することも検討する．

c) センサの誤差による影響

センサの誤差により, 対応した場所とは異 なる案内表示をし得ると考えられる.案 内表示に対する信頼度を定めておき，信頼 度以下ならば, 案内表示か間違っていると いう可能性を提示することも検討する . ま た , 使用する入力情報に対する優先順序に より情報集約することも検討する [11] .

d) カメラの搭載箇所

設置されるカメラの位置としては, 図 2 の 


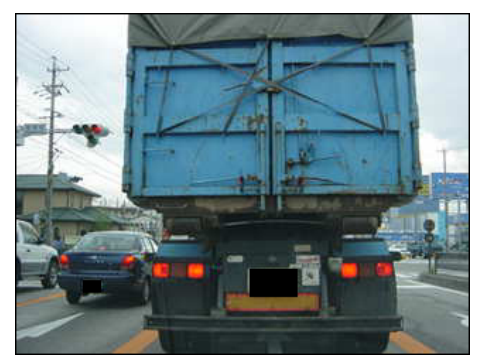

(a) Front vehicle

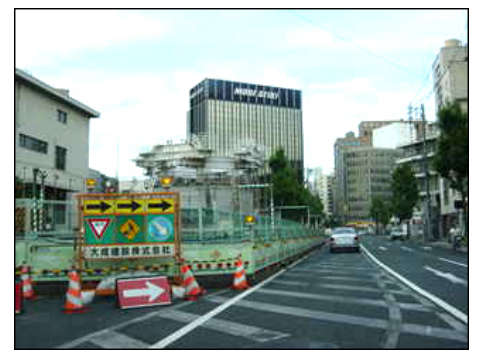

(b) Traffic work zone

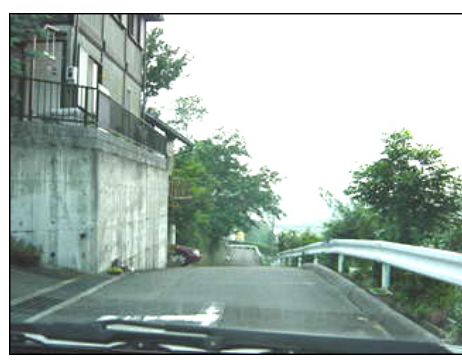

(c) Blind spot

图 11: 状況変化による道路噯蔽

Fig. 11: Occlusion of road by change of a situation and environment

例以外に前方のバンパー, フロントグリル なども考えられる．ドライバーズビューに 対応するために，運転者の視界に対応する ように実写動画像を幾何補正する。

\subsection{2 アルゴリズム上の問題点}

a）必要な道路幾何情報の整理 4.3 では，道路幾何情報を道路端としたが， 案内表示として必要な道路幾何情報は道路 端だけではないと考えられる．案内標識， 看板などを実写動画像から認識できれば， カーナビ表示内の対応する場所に, 標識等 を強調してユーザに提示することができ る.炎のため瞬時の視認性を向上させるた めに必要な道路幾何情報を検討する .

b) 道路幾何情報の遮蔽

図11(a)のように道路端の遮蔽により CV 技術で道路幾何情報が抽出できない．地 図情報と動画像の特性を利用して，前方の 状況を予測し，表示時においては遮蔽物を CG 道路で塗りつぶして前方の状況を提示 することも検討する .

c) 新設道路による道路状況の変化

図 11(b) のように道路状況が変化した場 合，あらかじめ用意された地図情報よりも 実写動画像から抽出された道路幾何情報の 方が, 視界風景に対して正確である.信頼 度に応じた情報集約により，ロバスト性を 向上させる . d) カメラの死角の考慮

図11(c)のように, 上り坂や下り坂, カー ブにおけるカメラの死角では , 実写動画像 からの道路幾何情報の抽出は主観的輪郭抽 出のような考え方を使用しない限り不可能 であるため, 実写動画像以外の入力情報に 依存する.案内表示では姿勢情報を用いて CG 道路等を幾何補正して提示する .

e) 撮影環境の考慮

悪天候，夜間などの環境下の場合，赤外線 カメラの使用も考慮している. 悪条件の道 路シーンには，正確に道路幾何情報を抽出 できない，もしくは瞬時の視認性が高い案 内表示を提示できないという二つの可能 性が考えられるため, センサの問題と同樣 に, 抽出精度, 案内表示に対する信頼度を 定め，信頼度以下ならば従来の 3D-CG の みのカーナビ表示に自動的に切り替えるこ とも必要である。

f）実写動画像と CG 道路の同期表示 臨場感のある表示をするためには，実写動 画像と CG 道路の同期表示が必要である . 速度情報は，車体の車速度センサと CV 技 術からの取得方法が考えられる.CV 技術 からの速度情報は, 車体からの速度情報 よりもフレーム間で対応できるため, 確か らしいと考えられる.CG 道路にはテクス チャを使用することも検討しており，道路 のテクスチャを車速同期して移動させるこ とにより臨場感の向上が期待される . 


\section{5 おわりに}

本論文では，AR 技術を利用した表示方式 を持つカーナビの構成形式を提案した . また， 本表示方式の瞬時の視認性を確認するために アンケート調査を行った . アンケート結果で は，85\%以上の被験者が従来のカーナビ表示 に比へ，本表示方式の方が良いと回答し，本 表示方式の有効性が示唆された .さらに, CG 道路の透過率の変化など, ユーザによって個 人差が生じることが確認された．また，試作 システムによる実験の結果，道路端抽出精度， 処理時間といった問題点が得られた . システ ム実装時に考慮すべき点とアルゴリズム上の 問題点を整理することで, 本研究を進めて行 く上での指針が得られた .

本表示方式は実際の風景を利用するため，フ ロントガラスを利用した案内表示方式 (HUD: Head-Up Display) [21，22] への応用が考えら れる.しかし，現在の日本の道路交通法にお いて , フロントガラスで案内表示することは 禁止されている．本表示方式を HUD に応用 することでユーザの視線移動が軽減されるこ とが期待されるため, 本表示方式の有効性と 安全性の基礎検討を行う必要がある。

今後の課題として，4.4 節で考察した事項 に加えて，従来のカーナビに使用される入力 情報を利用した道路幾何情報の抽出精度向上， ユーザの好みに合わせた効果的な案内表示の 調査·検討などが挙げられる.

\section{参考文献}

[1] 本田技研工業株式会社: “Honda 社史 50 年 史”, pp. 170-173 (1988)

[2] M. Moldenhauer and D. S. McCrickard. "Effect of Information Modality on Geographic Cognition in Car Navigation Systems", Short Paper in Proc. of INTERACT '03: the IFIP TC.13 Conf. on HumanComputer Interaction, pp. 837-840 (2003-9)

[3] 麻生勤, 宇野宏, 野口昌弘, 川崎由美子: “運 転中のカーナビ視認時間の許容限界の検討”,
日本自動車研究所, 自動車研究, Vol. 24, No. 3, pp. 29-32 (2002-3)

[4] 国土交通省道路局 ITS ホームページ， http://www.mlit.go.jp/road/ITS/ j-html/ (2005)

[5] F. Hu and K. Uchimura: "Solution of Camera Registration Problem via 3D-2D Parameterized Model Matching for On-road Navigation", Int'l J. of Image and Graphics, Vol. 4, No. 1, pp. 3-20 (2004)

[6] Z. Zhang, J. Wu, Y. Zhang, Y. Zhang and J. Zhang: "Multi-view 3D City Model Generation with Image Sequences", Proc. of the ISPRS Workshop on Vision Techniques for Digital Architectural and Archaeological Archives, Vol. XXXIV-5/W12, pp. 351-356 (2003-7)

[7] H. Sawano and M. Okada: "A Carnavigation System Based on Augmented Reality", Sketches of ACM SIGGRAPH 2005: 32nd Int'l Conf. on Computer Graphics and Interactive Techniques (Los Angeles, USA), 1 page (2005-8)

[8] 片山理, 上杉浩, 岡田稔: “案内画像生成装 置, 案内画像表示装置, ナビゲーション装置, 及びプログラム”, 公開特許公報, 特開 2003121167 (2003-4)

[9] 片山理, 上杉浩, 鎌田忠, 伊藤隆文, 岡田稔: “道路位置検出方法, 道路位置検出装置, プ ログラム”, 公開特許公報, 特開 2005-056128 (2003-8)

[10] O. Katayama, H. Uesugi, T. Kamada, T. Ito and M. Okada: "Road Position Detection" , US Patent Application [Appl. Ser. \#10/895, 964], (2004-6)

[11] 澤野弘明, 馬場吉史, 中村長生, 岡田稔: “

実写画像を利用したカーナビゲーションシ ステムの基礎検討”, 情報処理学会研究報告, 2002-CG-108-8, pp. 43-48 (2002-8)

[12] 澤野弘明, 馬場吉史, 岡田稔: “実写画像と CG の合成によるカーナビ表示方式の有効性 の検討”, FIT2003 情報科学技術フォーラム, pp. 357-359 (2003-9)

[13] R. T. Azuma: "A Survey of Augmented Reality", Presence of Teleoperators and Virtual Environments, Vol. 6, No. 4, pp. 355385 (1997-8) 
[14] 天目隆平, 神原誠之, 横矢直和: “ウェアラブ ル拡張現実感のための現実環境の三次元モデ ルを利用した情報提示”，電子情報通信学会 技術研究報告, PRMU2004-257, pp. 151-156 (2005-3)

[15] 寺田智広, 神原誠之, 横屋直和: “拡張現実 感を用いた車載型アノテーションシステム の構筑”, 電子情報通信学会技術研究報告, CQ2001-103, pp. 55-60 (2002-2)

[16] 津田崇博, 山本治由, 亀田能成, 大田友一: “ 死角を透視表示する屋外型複合現実感シス テムにおける提示手法の比較検討”, 電子情 報通信学会技術研究報告, MVE2005-34, pp. 41-47 (2005-9)

[17] 吉田忠雄, 矢野肇, 岡部政信: “ナビゲーショ ン方法, ナビゲーション装置及び自動車”, 公 開特許公報, 特開平 10-132598 (1998-5)

[18] H. Sawano and M. Okada: "Road Extraction by Snake with Inertia and Differential Features", Proc. of ICPR2004 - 17th Int'l Conf. on Pattern Recognition (Cambridge, UK), Vol. 4, pp. 380-383 (2004-8)

[19] H. Sawano and M. Okada: "A Road Extraction Method by an Active Contour Model with Inertia and Differential Features", $I E$ ICE Trans. Inf. Syst., Vol. E89-D, No. 7 (to appear, Jul. 2006)

[20] 辻新六, 有馬昌宏: “アンケート調査の方法 -実践ノウハウとパソコン支援-", 朝倉書店 (1987-11)

[21] 中村耕治, 安藤浩, 川原伸章: “ウインドシー ルドディスプレイによる安全で快適な画像情 報呈示”, 社団法人自動車技術会, 自動車技術, Vol. 6, pp. 49-54 (2005-6)

[22] A.M. Steinfeld and P. Green: "Driver Responses to Navigation Information on Fullwindshield, Head-up Displays", Int'l J. of Vehicle Design, Vol. 19, No. 2, pp. 135-149 (1998)

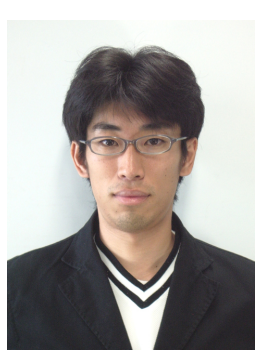

澤野弘明

平成 16 年中部大学工学部情報 工学科卒業, 平成 18 年早稲田大 学大学院情報生産システム研究科 修士課程情報生産システム工学専 攻修了, 同年同大学院博士後期課 程進学，現在に至る.コンピュー タビジョン,拡張現実感に関する 研究に従事 . 情報処理学会, 電子 情報通信学会, ACM 各学生会員 平成 16 年電気学会優秀論文発表賞, 平成 17 年電子情 報通信学会九州支部講演奖励賞各受賞。

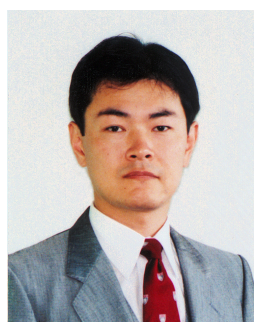

岡田 稔

昭和 59 年名古屋工業大学工学 部電気工学科卒業, 平成元年名 古屋大学大学院工学研究科博士 課程後期課程情報工学専攻修了。 工学博士. 昭和 $63 \cdot$ 平成元年度 日本学術振興会特別研究員, 平 成 2 年名古屋大学情報処理教育 センタ一助手, 平成 5 年同助教 授, 平成 10 年同大学院工学研究 科情報工学専攻助教授, 平成 11 年中部大学工学部教授 を経て, 平成 15 年 4 月早稲田大学大学院情報生産シ ステム研究科教授，現在に至る. 平成 7 年より 1 年間， 米国ミシガン大学客員准教授 . 画像とパターンの認識. 理解, 計算幾何学, 画像合成, 知能メディア情報処理の 基礎理論と応用に関する研究に従事. 電子情報通信学 会, 情報処理学会, 画像電子学会, ACM SIGGRAPH, IEEE Computer Society (Senior), Eurographics 各 会員. 平成 4 年度情報処理学会研究賞, 平成 6 年度市 村賞学術貢献賞，平成 12 年情報処理学会優秀教育賞各 受賞. 著書「Cによるプログラミング演習」(近代科学 社)，「情報科学基礎論」(朝倉書店)，「インターネット 時代のコンピュータ活用法」(コロナ社) 等。 